\title{
GADIR REVISITED. \\ A PROPOSAL FOR RECONSTRUCTION \\ OF THE ARCHAIC PHOENICIAN FOUNDATION
}

\author{
Ana Mª Niveau-de-Villedary y Mariñas* - University of Cadiz
}

Classical sources and academic tradition situate the Tyrian colony of Gadir under the current city of Cádiz, in southern Spain. However, it was not until the beginning of our millennium that archaeological research unearthed part of the urban grid, linked to the ancient foundation, confirming its location and antiquity. The aim of this paper is to gather and organize the disparate material data in order to reconstruct the topography, the morphology and the functionality of the archaic city of Gadir.

Keywords: Phoenician colonization; Gadir; archaic city; urban morphology; chronology

\section{INTRODUCTION}

According to classical tradition, ${ }^{1}$ the Tyrians founded Gadir in the Mediterranean West end, under the current city of Cádiz (SW Spain) (fig. 1), approximately 80 years after the fall of Troy.

The great transformation experienced by the landscape in the last three thousand years (figs. 2-3) is the main difficulty to identify the ancient place names and the location of settlements and temples referenced in the written sources.

Today, Cádiz is situated on an elongated peninsula, which is attached to the mainland by a narrow strip of land $(14 \mathrm{~km})$, although in antiquity, it was part of an archipelago, ${ }^{2}$ (Arteaga, Schulz and Roos) constituted at least by three islands, which have been identified as those referenced by the classical authors (fig. 4).

The smallest island, located to the North, was divided by a strip of sea, which was blocked during the Roman period by human activity, and known as the "Bahía-Caleta channel”. ${ }^{3}$ Most classical and modern authors place the ancient Phoenician city ${ }^{4}$ and the sanctuary to Venus Marina, the Phoenician Astarte, ${ }^{5}$ on this island.

On the other side of the ancient sea channel, lay the larger island, elongated in shape, known as Kotinoussa by Timaeus. ${ }^{6}$ On this island, a temple dedicated to Kronos (originally Baal-Hammon) was constructed in the northern tip, while a temple to Herakles (the

\footnotetext{
* This study is the result of the activities by the Research Group HUM-509 'Phoenix Mediterrane' and the CEIMAR It was carried out thanks to a research stay at the University of Oxford in 2017 with the support of the program "Salvador de Madariaga”, Government of Spain. The author would like to thank Carolina LópezRuiz, Nicholas Purcell and Josephine C. Quinn for their kind and invaluable assistance, advise, and criticism. I would like to extend my acknowledgment to Francisco Núñez and Alfredo Mederos. (AM N-D-V M) Department of History, Geography and Philosophy, Faculty of Arts, University of Cádiz, Avda. Gómez Ulla s/n. 11003 - Cádiz, SPAIN, anamaria.niveau@uca.es.

1 Vell. Pat., Hist. Rom., I, 2, 3 and I, 8, 4; Str., I, 3, 2; Mel., III, 6, 46; Plin., N.H., XIX, 216; Ps.-Arist., De mirabil. ausc. 134.

Arteaga - Schulz - Roos 2008.

Niveau-de-Villedary 2010, 637.

Plin., N.H., IV, 36, 120; Ramírez 1982.

Avienus, O.M., 319-317.

Plin., N.H., IV, 4, 119-120.
}

ISSN 0393-0300

e-ISSN 2532-5159 
Phoenician Melqart) was erected in the southern end. The Phoenician city was probably transferred here, once the original urban centre, to the North of the channel, was abandoned, expanding later, during the Roman period, due to lack of space (Str., III, 5, 3).

\section{THE “DISCOVERY” OF THE ARCHAIC CITY}

In general, the majority of the first findings belong to funerary or sumptuary contexts. ${ }^{7}$ Therefore, cemeteries and temples are much better known than the city itself. The lack of habitational remains led to the proliferation of theories and speculations concerning the location of the city and the urban character of the island site. ${ }^{8}$ However research has experienced a complete turn these past years, following the uncovering of urban remains of varied character and entity in different points of the city. ${ }^{9}$ Early data were partial and found almost entirely in the surroundings of Kotinoussa, the larger island located to the South of the channel. ${ }^{10}$ The finds were recovered from a secondary position (CP) (fig. 5:1) and unclear contexts, associated to possible Phoenician remains (walls and pavements), which were severely affected by later constructions (CAr/CB) (fig. 5:2). These are material ensembles (western Phoenician amphorae T-10.1.2.1., red-slipped plates with narrow rims, double-spouted lamps, bichrome vessels) that should be dated to an advanced moment between the $7^{\text {th }}$ or $6^{\text {th }}$ centuries $\mathrm{BC},{ }^{11}$ excepting some residual finds, which may be traced back to the mid $8^{\text {th }}$ century BC (eastern Phoenician amphorae Sagona 2).

Around the same time, a sounding was conducted in the high grounds of the northern island (the ancient Erytheia), where tradition placed the oldest Phoenician settlement (TT/MRT) (fig. 5:3). The results, however, were confusing, for no clear evidence appeared for archaic material and it had not been determined whether there were any deeper archaeological levels. ${ }^{12}$ Another archaeological intervention on the shores of the ancient channel (TA) (fig. 5:4) recorded the archaic coastal line and remains of undefined human activity which were interpreted as "consumption areas", based on materials dated since the $7^{\text {th }}$ century BC.

In 2002, with the aim of drawing out the course of the channel, a series of geoarchaeological surveys took place, which provided evidenced for the existence of an inner harbour, or kothon, functioning as of just as the one of the archaic period (PC) (fig. $5: 5)^{13}$

At the end of the twentieth century the first clearly Phoenician levels were excavated and brought to light. Again, the first finds came from the "long" island of Kotinoussa south of the channel. Between 1997 and 2000, the episcopal palace was excavated ("Casa del Obispo" archaeological site) (fig. 5:6), next to the city's modern cathedral. ${ }^{14}$ The excavation returned an uninterrupted sequence of occupation at the site from the Bronze

Niveau-de-Villedary 2008, 85.

Niveau-de-Villedary 2010.

Botto ed. 2014.

Frutos - Muñoz 2004, 87-88.

Or even later, see Ruiz Mata 2016, 309.

Ruiz Mata 2016, 308.

Arteaga - Roos 2002

Gener et al. 2014a. 
Age onwards. The lower levels were interpreted as an "extra-urban”, domestic, habitational area.

However, the most significant discoveries, related to the archaic Phoenician site, have been unearthed at Erytheia where tradition places the original Phoenician city. In 2002, a temporary settlement was excavated on the north shore of the channel (CdO), with no permanent structures and a single moment of occupation towards the beginning or the end of the $8^{\text {th }}$ century BC ${ }^{15}$ (fig. 5:7).

In the same year, another excavation was conducted to the north of the island, in front of the site where a figurine with a golden mask had been discovered back in 1928, now exhibited in the National Archaeological Museum in Madrid (CT) (fig. 5:8).

The new excavations (2002) brought to light the archaic Phoenician occupation (CA) (fig. 5:9), although without construction features, except for a pit with a well dug in its interior, ${ }^{16}$ may evidence ritual activities rather than occupation in this area. Both structures were filled with pottery and bone. This excavation (CA) is similar to the previous site $(\mathrm{CdO})$ in terms of chronology and culture. A single level of occupation was recorded, which was subsequently abandoned, and the place was not reoccupied until the $3^{\text {th }}$ century BC.

Finally, the archaeological intervention on the highest topographic point of the city (fig. 5:10) (under the former "Teatro Cómico") has unearthed evidence for the urban grid of the ancient Phoenician city. ${ }^{17}$ The excavation furthermore recorded the first sequence of continued Phoenician occupation on Erytheia (from the end of the $9^{\text {th }}$ century BC to the third quarter of the $6^{\text {th }}$ century BC approximately). Four Phoenician phases were identified: Period I (Late Bronze Age/Phoenician: $9^{\text {th }}$ century BC ante circa 820/800 BC), Period II (Phoenician A: 820/800 BC - 760/750 BC) (fig. 6), Period III (Phoenician B: late $8^{\text {th }}$ century BC $-600 / 580$ BC), Period IV (Phoenician C: from the second quarter of the $6^{\text {th }}$ century $\mathrm{BC}$ to the third quarter of the $6^{\text {th }}$ century $\mathrm{BC}$ ).

The data recovered (urbanism, domestic architecture, construction materials and techniques from the Levant, writing, material culture, etc.) point to an eastern origin for the remains of the ancient city and place the moment of foundation, according to the excavators, towards the late $9^{\text {th }}$ century $\mathrm{BC},{ }^{18}$ confirming the insular nature of the first Tyrian settlement and its antiquity.

The earliest funerary remains of Gadir were also recently found on Erytheia. ${ }^{19}$ They would belong to the cemetery serving the excavated sector of the city $(\mathrm{CH})$ (fig. 5:11). Finally, recent works around La Caleta beach have returned data on potential Phoenician temples, dated at least to the $7^{\text {th }}$ century BC ${ }^{20}$ (fig. 5:12).

Córdoba - Ruiz Mata 2005.

Ruiz Mata et al. 2014

Gener et al. 2014b.

Torres et al. 2014, 79.

Sáez - Belizón 2014.

Maya et al. 2014; Sáez - Higueras-Milena 2016. 


\section{DISCUSSION. TOPOGRAPHY AND MORPHOLOGY OF THE URBAN INSULAR SETTLEMENT OF GADIR IN ARCHAIC TIMES}

As some scholars have noted, the data are still very fragmentary and limited, rendering it difficult to establish a logical, functional and sequential order for the inhabited and productive space. ${ }^{21}$ Nevertheless the intention here is to articulate the available information, in order to specify the nature and extension of the urban centre per se, as well as its (spatial and functional) limits, the potential extra-urban spaces and their functions, and the city harbours. Let us not forget moreover the integration of the cemeteries and spaces of worship and their interpretation in relation to the city.

\subsection{Main urban area}

Some authors have suggested a horizontal stratigraphy for the urban settlement, given the apparent dispersion of urban remains. ${ }^{22}$ However there are sufficient historical, topographic, chrono-stratigraphic and morphological evidences to defend the view that the main urban centre of Gadir was located on the highest point of Erytheia (fig. 7).

The Phoenician topography differed greatly from the present (fig. 8:1). The first dwellings found under the "Teatro Cómico" site (TC) (fig. 8:2) rise only six meters over the level of the ancient shoreline, as part of a pre-littoral dune landscape. ${ }^{23}$ It was a slight, natural elevation, accessed by sea through the channel, although protected towards the interior.

There is consensus regarding the reduced size of the original urban site. Strabo describes the city prior to the expansion of Balbus as small (III, 5, 3) (fig. 8:3), although it is only possible to speculate on the actual dimensions of the site. The 10 ha proposed by some calculations appear excessive ${ }^{24}$ and perhaps reality was closer to the single hectare suggested by Domínguez Monedero. ${ }^{25}$ The total excavated extension at "Teatro Cómico" is only 470 square meters, although remains clearly continue under the four sections of the archaeological site. ${ }^{26}$ The linear distance between the different excavated points does not exceed a hundred meters, so it may be concluded that the urban centre did not extend much further from the tell crowning the current, most elevated topographical point (fig. 9). Settlement would have spread throughout the elevation and descended to the shore of the channel, adapting to the conditions of the terrain. In fact, the dwellings of the first Phoenician city were arranged along, at least, two terraces.

In time, the main urban centre would have been reduced, for only the central area shows a sequence of occupation spanning the three centuries (late $9^{\text {th }}$ century BC - third quarter of the $6^{\text {th }}$ century BC) (fig. 7:4). The remainder of the recorded places were only occupied during the first phase, and later abandoned for unknown reasons.

Another of the characteristics defining the Phoenician city is its elevated occupation density. All the excavated space at "Teatro Cómico" was occupied during Phoenician

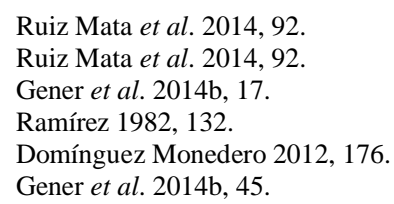


Period A and continued in occupation throughout successive reconstructions, indicating a high occupation of the terrain, which would have kept barely any non-urbanized spaces. ${ }^{27}$

As for the morphology and the characteristics of the city, the excavated sector constituted a residential area. A planned, orthogonal grid is recorded, with clearly eastern architecture, expressed in forms and techniques, as well as in subsidiary elements, such as furnaces. Other aspects, such as the continued renovation of the streets, constitute irrefutable proof for civic communal activities. ${ }^{28}$

Evidence for writing ${ }^{29}$ and administrative activities ${ }^{30}$ also confirm the urban character of the settlement. The size and disposition of the rooms in the buildings, as well as the activities performed in them (cooking, crafts destined for self-consumption, etc.), suggest a private-domestic nature for these structures.

There is no indication of the presumed city walls, which contrasts with the powerful defence structures recorded at the settlements along the bay's mainland shore (Castillo de Doña Blanca and Cerro del Castillo) ${ }^{31}$. In this regard, Ruiz Mata has suggested the existence of a "dispersed" insular habitat, as part of an "open city" with no walls. ${ }^{32}$ However, when considering toponomy and tradition, ${ }^{33}$ the city should have been enclosed by a wall.

In sum, the original city of Gadir was located to the south of the island of Erytheia, over a slight, natural elevation. The acropolis or public area was found in the current, most elevated topographical point. The residential area spread along its sides (as evidenced by the important excavated sector of dwellings) and reached the ancient course of the BahíaCaleta channel to South and East, where the peri-urban limits of economic activity have been recorded. The city possibly extended westward and northward, although there is no certainty of it. To the North, it would have bordered with an open, non-urbanized space, which was nonetheless occupied, dedicated to ritual activities related with the presumed cemetery of the city.

\subsection{Delimitation and functionality of the Erytheia peri-urban Space}

Despite difficulties in locating concrete, physical boundaries for the city, an attempt will be made to fix them, using functional criteria.

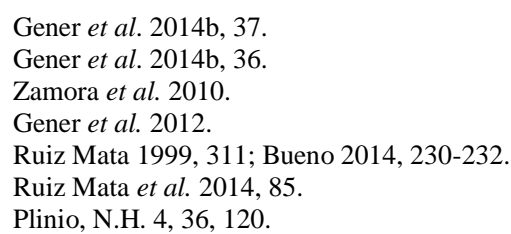


3.2.1. The southern and eastern limits: harbour and economic areas in relation to the channel

The southern limit of the settlement coincides with northern shore of the channel. A Phoenician beach level was recorded in this area at an altitude of $0.38 \mathrm{~m}$ a.s.l., ${ }^{34}$ only $77 \mathrm{~m}$ away from the excavated residential area. In this sector (TA), although undefined, early human activity was recorded (perhaps representing hearths or a dumping site). In all probability, the remains were deposited by regular movement in the area, given the proximity of the city, caused by activities related to the self-consumption of the workers at the anchorage area or by the coming and going of goods. ${ }^{35}$ Nevertheless it is difficult to clarify the extent to which the "harbour sector" or mooring area was actually integrated into the urban structure of the city.

The eastern limit is given by the occasional habitational remains found in 2002 (CdC), approximately $200 \mathrm{~m}$ in a straight line from the urban centre (TC) and 215-220 $\mathrm{m}$ from the above-mentioned coastal point (TA). The pavements and structures found would have belonged to the southern, peri-urban sector of the city, an open-air place of work related with fishing and the primary processing of the catch, which would have been unloaded in the nearest mooring points. This area would have remained outside the strictly-urban limits, although it was part of the peri-urban "outskirts", where diverse economic activities took place. These activities were related to the exploitation of marine resources and commerce, the limits of which varied through time.

\subsubsection{The northern limit: ritual and/or burial areas?}

The existence of a necropolis on Erytheia was already suggested over thirty years ago by Ramírez Delgado ${ }^{36}$ who alluded to the possibility of finding the archaic cemetery in the immediate limits of the city. This idea was based on the discovery in the early twentieth century of a Ptah figurine (known as the "Priest of Cádiz"), inside a structure interpreted as a monumental grave (CT), approximately $150 \mathrm{~m}$ North of the main residential area (TC).

The discussion surrounding the function of the remains was revived when further findings appeared in the last 15 years (CA), scarce $20 \mathrm{~m}$ from the previous ones (CT). The well that was excavated was initially interpreted as a Phoenician tomb, but subsequent material and contextual analysis suggested a votive function for the remains, although still in relation to the cemetery. ${ }^{37}$ The deposit showed a succession of different rituals and sacrifices and possible ritual or funerary banquets. ${ }^{38}$

\subsection{The harbours}

The location of the Phoenician harbour is another of the questions dominating the history of research on Gadir. Modern authors located it first on La Caleta beach (West), moving later towards the open bay area in the Roman period (East). After the identification of the inner channel, a double Phoenician harbour was proposed: a military one in La

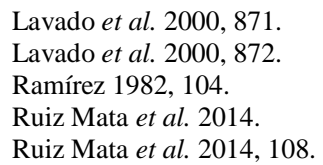


Caleta and a commercial one in a secondary cove (so-called "Puerto Chico"), open to the sea on the "Vendaval front". They would have been connected by an artificial canal. Other authors believe that the Phoenician harbour was protected, located towards the interior of the channel, at the foot of the city's hill. ${ }^{39}$ The coming and going of ships and the construction of structures related to the harbour would have eventually caused a blockage in the water course. The most recent research on the subject has proven the existence of this "inner harbour" in the current "Plaza de la Catedral". The harbour would have functioned continuously from the late $9^{\text {th }}$, beginning of the $8^{\text {th }}$ centuries BC, until the Roman period. ${ }^{40}$ Arteaga suggests that the Phoenicians established their first settlement around this inner harbour or kothon, in a similar way as the eastern karum, in relation to their neighbouring local populations. ${ }^{41}$

Summing up, there would have existed two outer harbours, one opening towards the Atlantic (La Caleta beach) and another towards the bay (at the location of the current port), and at least another three inner harbours: two shallow mooring areas on the Atlantic front, and the more important one, the kothon, or inner harbour, located in the area of the modern cathedral.

\subsection{Extra-urban areas in Kotinoussa}

The data collected from the northern point of the island of Kotinoussa are generally later in chronology. It was probably an area of urban or peri-urban expansion, since the $7^{\text {th }}$ $6^{\text {th }}$ centuries BC, dedicated to industrial and sea-faring activities, or even ritual activities, in relation to the nearby temples.

The construction remains around the cathedral/"Casa del Obispo" (CdO) have been considered extra-urban by the excavators, although domestic in function. ${ }^{42}$ According to other authors, this area would have been part of the city, characterized by a dispersed habitat. ${ }^{43}$ Another possibility points towards a social differentiation, so that this area would belong to a "popular sector", developed in the outskirts of the more accommodated residential areas. The discovery of a metalworking nozzle testifies to this activity in the area, ${ }^{44}$ possibly indicating that this was a peri-urban industrial, and not a domestic, sector, as proposed by the excavators. Finally, it is also possible that the area was intended for religious activities as it was in the later periods.

To sum up, the possible construction and material remains enable to interpret the area as peripheral neighborhoods or as extra-urban industrial installations, related to religion, seafaring, etc. However that may be, they do not seem to belong to the main habitational centre, located to the north of the channel. Since the late $7^{\text {th }}$ century BC, the area to the south began to be used as a cemetery. ${ }^{45}$

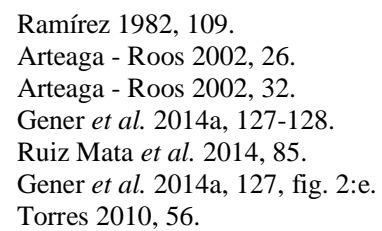




\subsection{The (presumed) Archaic Cemetery located north of Erytheia}

From a historiographical standpoint, there exist two positions in regard to the location of the city's first cemetery. According to some scholars the archaic cemetery would be situated in Erytheia, to the north of the settlement. This theory is based on the discovery of the assumed monumental grave, in which the above-mentioned golden-headed figurine, known as the "Cádiz priest", was found. Other scholars disagree, placing the Phoenician cemetery south of the older city, on Kotinoussa. The latter base their position on two main arguments. Firstly, spatial-temporal continuity is considered, for the later cemetery occupies this area. Secondly, topography must be considered, since the usual Phoenician settlement pattern requires a physical and symbolical separation between the habitational and funerary areas, which is normally established by a course of water. For Gadir, this would have been the ancient channel traversing the historical centre of the city. However, the discovery in 2010 of an archaic grave $(\mathrm{CH})^{46}$ approximately $500 \mathrm{~m}$ to the north of the main urban centre supports the existence of an archaic cemetery on Erytheia. It is a cremation in primary grave, similar in terms of ritual to the late archaic burials of Gadir, although different from Phoenician funerary features recorded for the same time period in other areas, including "popular and plains" necropolises like that of the eastern metropolis, Tyre-Al-Bass, ${ }^{47}$ as well as "aristocratic-segmented" cemeteries. ${ }^{48}$ In both cases, the burial ritual is the secondary cremation, followed by a later deposition of the ashes in urns. The artefacts found inside the Gaditanian grave do not respond to the normalized funerary set found in Phoenician graves. The pottery assemblage included both hand-made and wheeled plates and drinking bowls and some sumptuary items (incense burners, ivory plate, etc.), which may be traced to eastern prototypes, although they also remind of indigenous traditions.

Although, data is still very partial, it is possible to suggest, based on what is already known, a preliminary hypothesis for the existence of Phoenician cemeteries of diverse nature - "aristocratic" and "plains" - distributed throughout the insular landscape. ${ }^{49}$

\subsection{Temples and places of worship. Buildings or sacred landscape?}

The classical sources mention the existence of up to three temples on the islands (see above, $\S 1$.). These references, when jointly considered with the lack of space, material evidence and the reduced size of the settlement, have led some authors to propose a sacred or symbolic role for the island site. ${ }^{50}$ According to this explanation, the majority of the population would have lived in the urban centres of the mainland, where the political and administrative power would also have been found, concentrating the majority of the economic activity. ${ }^{51}$ Without reaching this extreme conclusion, since the urban character of the excavated area on Erytheia is undeniable, the reality is that the three temples mentioned

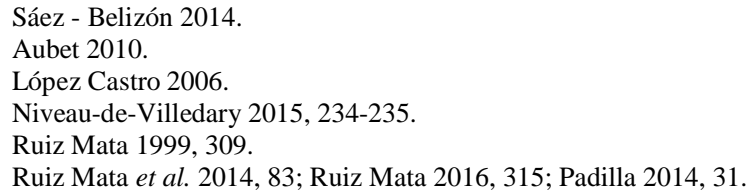


in the sources were erected on these islands, as well as a series of other sacred spaces, both public and private.

The temple to Melqart, situated on the southernmost side of Kotinoussa, is left, from a spatial perspective, out of this analysis. It would have represented, both physically and symbolically, the southern limit of Gadir and it should be related to the mainland settlement of Cerro del Castillo (Chiclana, Cádiz). The other two sanctuaries are located in the northern extremity, close to the city. Although different locations have been suggested for the sanctuary dedicated to Astarte, the most accepted proposal is the northern end of La Caleta beach (in Erytheia), while the Kronion, ancient sanctuary of Baal-Hammon, may have been located in the North-West point of Kotinoussa. Nonetheless, there is no clear evidence supporting any of the cases. The location of the sanctuary of Astarte is based on the underwater discovery of a group of terracotta figures and vessels related to the cult. Recent underwater interventions are allowing to identify the points, where finds are more frequent, contributing to the increase in knowledge related to the activities performed at the place since the earliest times. ${ }^{52}$ There is no certainty regarding the existence of the Kronion at the proposed location, which is only supported by the discovery of a proto-Aeolian capital in the surroundings, which has led some authors to suggest this was a sacred place, without constructions. ${ }^{53}$ Nevertheless, in the last years, a series of archaeological interventions have brought to light remains of constructions and artefacts dated from the $7^{\text {th }}$ century onwards, which are still awaiting assessment. ${ }^{54}$

Another sacred area is that which surrounding the current cathedral, on the longer island. This space became sacred towards the late $6^{\text {th }}$ century BC, when offerings and small banquets began taking place around a monumental grave, apart from the general cemetery. ${ }^{55}$ The archaic remains recorded under this structure were interpreted as domestic spaces by the excavators, although their religious nature should not be overlooked, given the sacred continuity of the place in later periods and its prominent topographic position.

\section{Conclusions. Chronology And DEVElopment OF THE PHOENICIAN CITY}

The earliest occupation of the Gaditanian site may be traced back to an undetermined moment during the late Neolithic/Chalcolithic. This period is followed by a hiatus in human occupation, prolonged until the arrival of eastern populations. Although there are indications for an earlier occupation (Period I - Late Bronze Age/Phoenician), ${ }^{56}$ the earliest confidently recorded levels in Gadir pertain to Period II - Phoenician A, from the urban sector excavated at Erytheia at the Teatro Cómico excavation. ${ }^{57}$

Hence, from a sequential standpoint, there are no levels recorded in Gadir, belonging to an early foundation of the city in the "Early Colonial Horizon", defined in recent years after the finds at Huelva/Plaza de las Monjas, La Rebanadilla (Málaga) and El Carambolo (Seville), in the Iberian Peninsula, and at Utica (Tunisia), in the central Mediterranean. ${ }^{58}$

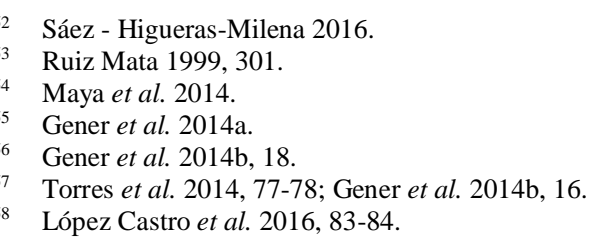


On balance, it is a question which remains open waiting for the development of further research, which may record an "Initial Archaic Phase".

After this first, still hypothetical, phase, an "Early Archaic Phase” is clearly defined for Gadir, mainly represented by Period II - Phoenician A at Erytheia/Teatro Cómico, which began sometime around 820/800 BC and ended towards 760/750 BC. ${ }^{59}$ It corresponds with Stratum IV at Tyre and its transition to Stratum III; with the transition between the "Salamis Horizon" (850-750 BC) and the "Kition Horizon" (750-700 BC) at Cyprus; and with Periods III-IV at the cemetery of Al-Bass. ${ }^{60}$ However, the first recorded pavements may go back to Stratum V at Tyre. ${ }^{61}$ This stage is contemporary with Phase B1 at Morro de Mezquitilla and Phases III-II at La Rebanadilla.

The peri-urban sectors of the main urban centre at Erytheia (CdC and CA) correspond, according to the excavators, with Strata III-II at Tyre, due to the presence of narrow rimmed plates and local-western amphorae T-10.1.1.1. ${ }^{62}$ Some earlier types could be connected to Tyre IV, although Ruiz Mata prefers to date this single-phased occupation horizon to the first half or mid $8^{\text {th }}$ century BC. ${ }^{63}$

The beginning of human occupation on Koutinussa (CdO) is also dated ca. 820/800 BC. ${ }^{64}$ First activity on the island has been proposed as contemporary to Phase 1 of Period II at Erytheia/TC. ${ }^{65}$

As for funerary spaces, the burial to the north of the settlement $(\mathrm{CH})$ was generically dated to the $8^{\text {th }}$ century $\mathrm{BC}$ or to the central years or second half of the same century, ${ }^{66} \mathrm{a}$ chronology confirmed by radiometric dating.

Few data have been recorded for other spaces. It has been suggested that the inner harbour would have been functioning starting from the transition from the $9^{\text {th }}$ to the $8^{\text {th }}$ centuries BC. ${ }^{67}$ Evidence for religious spaces appear later in time, dated to the end of the $7^{\text {th }}$ - beginning of $6^{\text {th }}$ centuries BC. ${ }^{68}$

With the available data, and by integrating different approaches, it is possible to support a preliminary date between 790-780 BC for the beginning of the occupation represented by Period II at Teatro Cómico - without dismissing the existence of an earlier phase, which is still poorly defined - which reached a maximum expansion of the urban centre in the mid $8^{\text {th }}$ century. These dates conform with the relative and absolute dates from other sites with similar levels and with the first productive facies defined for the Far-western Phoenician colonies. ${ }^{69}$

From this perspective, the existence of an archaic city becomes increasingly plausible, emerging at an undetermined moment of the $9^{\text {th }}$ or beginning of the $8^{\text {th }}$ centuries $\mathrm{BC}$, reaching its greatest spatial development towards the mid $8^{\text {th }}$ century BC. Another question

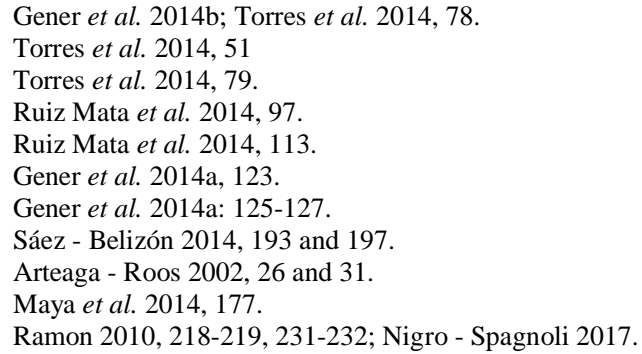


requiring clarification is the reason why the main urban centre remained in the same place for close to three centuries, while the peri-urban limits experienced a single-phase occupation, dated only to the early years. Was the original urban area reduced? Did it expand to other, previously extra-urban, areas? Or are we facing a dispersed habitat, lacking a walled enclosure? Many questions still remain unanswered.

\section{REFERENCES}

Arteaga, O. - Roos, A.M.

2002 El puerto fenicio-púnico de Gadir. Una nueva visión desde la geoarqueología urbana de Cádiz: Revista de prehistoria y arqueología de la Universidad de Sevilla 11 (2002), pp. 21-39.

Arteaga, O. - Schulz, H. D. - Roos, A.M.

2008 Geoarqueología Dialéctica en la Bahía de Cádiz: Revista Atlántica-Mediterránea de AuBET, M.E. Prehisotria y Arcquelogiía Social 10 (2008), pp. 21-116.

2010 The Phoenician Cemetery of Tyre: Nar Eastern Archaeology 73.2/3 (2010), pp. 144-155.

Bотто, $\mathrm{M}$.

2014 Los fenicios en la Bahía de Cádiz: estrategias de poblamiento y de aprovechamiento del territorio, relaciones con el mundo indígena, comercio (siglo IX - finales del siglo VII/inicios del VI a.C.): M. Botтo (ed.), Los Fenicios en la Bahía de Cádiz: Nuevas Botтo, M. (ed.) investigaciones (Collezione di Studi Fenici 46), Pisa - Roma 2014, pp. 265-281.

2014 Los Fenicios en la Bahía de Cádiz: Nuevas investigaciones (Collezione di Studi Fenici 46), Pisa - Roma 2014

BuENO, P.

2014 Un asentamiento del Bronce Final - Hierro I en el Cerro del Castillo, Chiclana, Cádiz. Nuevos datos para la interpretación de Gadeira: M. BotTo (ed.), Los Fenicios en la Bahía de Cádiz: Nuevas investigaciones (Collezione di Studi Fenici 46), Pisa - Roma, pp. 225251.

CÓRDOBA, I. - RUIZ MATA, D.

2005 El asentamiento fenicio arcaico de la calle Cánovas del Castillo (Cádiz). Un análisis preliminar: S. CELEstino - J. JimÉNEz (eds.), El Periodo Orientalizante (Anejos de Archivo Español de Arqueología XXXV-2), Mérida 2005, pp. 1269-1322.

DOMínguez MONEDERO, A.

2012 Gadir: C. ForNis (ed.), Mito y arqueología en el nacimiento de ciudades legendarias de la Antigüedad, Sevilla 2012, pp. 153-197.

Frutos, G. - MuÑOZ, Á.

2004 La implantación colonial fenicia arcaica en el archipiélago de las Gadeira: una propuesta para el debate: Huelva en su Historia $2^{a}$ Época 11 (2004), pp. 83-106.

Gener, J.M. - NAvarro, M.A. - PAjuelo, J.M. - Torres, M. - Domínguez-Bella, S.

2012 Las crétulas del siglo VIII a. C. de las excavaciones del solar del Cine Cómico (Cádiz): Madrider Mitteilungen 53, pp. 134-186.

Gener, J.M. - Jurado O, G. - PAJuelo, J.M. - Torres, M.

2014a El proceso de sacralización del espacio en Gadir: el yacimiento de la Casa del Obispo (Cádiz), Parte I: M. BotTo (ed.), Los Fenicios en la Bahía de Cádiz: Nuevas investigaciones (Collezione di Studi Fenici 46), Pisa - Roma 2014, pp. 123-155. 
Gener, J.M. - Navarro, M.A. - PAjuelo, J.M. - Torres, M. - López Rosendo, E.

2014b Arquitectura y urbanismo de la Gadir fenicia: el yacimiento del "Teatro Cómico" de Cádiz: M. BotTo (ed.), Los Fenicios en la Bahía de Cádiz: Nuevas investigaciones (Collezione di Studi Fenici 46), Pisa - Roma 2014, pp. 14-50.

Lavado, M.L. - Molina, M. - CoBos, L. - Blanco, F. - Sibón, F.

2000 El asentamiento antiguo de Cádiz a través de las últimas excavaciones arqueológicas: Actas del IV Congreso Internacional de Estudios Fenicios y Púnicos (Cádiz, 1995), Cadiz 2000, pp. 869-879.

LÓPEZ CASTRO, J.L.

2006 Colonials, merchants and alabaster vases: the western Phoenician aristocracy: Antiquity 80 (2006), pp. 74-88.

López Castro, J.L. - FerJaoui, A. - Mederos, A. - Martínez-Hahnmüller, V. - Ben-Jerbania, I.

2016 La colonización fenicia inicial en el Mediterráneo Central: nuevas excavaciones arqueológicas en Utica (Túnez): Trabajos de Prehistoria 73/1 (2016), pp. 68-89.

MAyA, R. - JuRAdo, G. - GeNER, J.M. - TORRES, M. - LÓPEZ Rosendo, E. - ZAMORA, J.Á.

2014 Nuevos datos sobre la posible ubicación del Kronion de Gadir: las evidencias de época fenicia: M. Bотто (ed.), Los Fenicios en la Bahía de Cádiz: Nuevas investigaciones (Collezione di Studi Fenici 46), Pisa - Roma 2014, pp. 156-180.

NigRO, L. - SPAGNOLI, F.

2017 Landing on Motya. The earliest Phoenician settlement of the 8th century BC and the creation of a West Phoenician cultural identity in the excavations of Sapienza University of Rome - 2012-2016 (Quaderni di Archeologia Fenicio-Punica, Colour Monograph 04), Rome 2017.

NIVEAU-DE-VILLEDARY, A.M.

2008 Estado de la cuestión y nuevas perspectivas de la arqueología púnica en la Península Ibérica: el caso de la bahía de Cádiz: J.P. ViTA - J.A. ZAMORA LóPEZ (eds.), Nuevas Perspectivas II: La arqueología fenicia y púnica en la Península Ibérica (Cuadernos de Arqueología Mediterránea 18), Barcelona 2008, pp. 81-127.

2010 “Deconstruyendo” paradigmas. Una (re)visión historiográfica crítica al modelo interpretativo tradicional del Cádiz fenicio-púnico a la luz de los nuevos datos: E. FERRER Albelda (ed.), Los Púnicos de Iberia: proyectos, revisiones, síntesis (Mainake 32-I), Málaga 2010, pp. 619-671.

2015 La estructuración del espacio urbano y productivo de Gadir durante la Fase Urbana Clásica: cambios y perduraciones: Complutum 26/1 (2015), pp. 225-242.

PADIlla, A.

2014 Los inicios de la presencia fenicia en Cádiz: Gerión 32 (2014), pp. 15-56.

RAMÍREZ, J.R.

1982 Los primitivos núcleos de asentamiento en la ciudad de Cádiz, Cádiz 1982.

RAMON, J.

2010 La cerámica fenicia del Mediterráneo Extremo-Occidental y del Atlántico (s. VIII - 1R 1/3 del VI AC). Problemas y perspectivas actuals: Motya and the Phoenician Ceramic Repertoire between the Levant and the West (9th-6th century BC) (Quaderni di Archeologia Fenicio-Punica V), Roma 2010, pp. 211-253.

Ruiz MATA, D.

1999 La fundación de Gadir y el Castillo de Doña Blanca: Contrastación textual y arqueológica: Complutum 10 (1999), 279-317.

2016 Las ciudades fenicias del Castillo de Doña Blanca y Cádiz durante el s. VIII a.C. Mi visión actual según los datos recientes: M. BotTO - S. FinOCHI - G. GARBATI - I. OGGIANO (eds.), Lo mio maestro e'l mio autore. Studi in onore di Sandro Filippo Bondì (Rivista di 
XXII (2018) Gadir revisited. A proposal for reconstruction of the archaic Phoenician foundation

Studi Fenici XLIV), Roma 2016, pp. 305-318.

Ruiz Mata, D. - PÉREZ, C. J. - Gómez, V.

2014 Una nueva zona fenicia de época arcaica en Cádiz: el solar de la "Calle Ancha, n 29": M. Bотto (ed.), Los Fenicios en la Bahía de Cádiz: Nuevas investigaciones (Collezione di Studi Fenici 46), Pisa - Roma 2014, pp. 83-122.

SÁEZ, A.M. - BELIZÓN, R.

2014 Excavaciones en la calle Hércules, 12 de Cádiz. Avance de resultados y primeras propuestas acerca de la posible necrópolis fenicia insular de Gadir: M. BotTo (ed.), Los Fenicios en la Bahía de Cádiz: Nuevas investigaciones (Collezione di Studi Fenici 46), Pisa - Roma 2014, pp. 181-201.

SÁEZ, A.M. - Higueras-Milena, A.

2016 Cerámicas fenicias arcaicas de procedencia subacuática del área de la Caleta (Cádiz): ensayo de contextualización e interpretación histórica: Cuadernos de Prehistoria y Arqueología de la Universidad Autónoma de Madrid 42 (2016), pp. 119-142.

TORRES, M.

2010 Sobre la cronología de la necrópolis fenica arcaica de Cádiz: A.M. NIVEAU-DEVILLEDARY - V. GOMEz (eds.), Las necrópolis de Cádiz. Apuntes de arqueología gaditana en Homenaje a J.F. Sibón, Cádiz 2010, pp. 31-67.

Torres, M. - LóPez Rosendo, E. - Gener, J.M., NAVArro, M.A. - Pajuelo, J.M.

2014 El material cerámico de los contextos fenicios del "Teatro Cómico” de Cádiz: un análisis: M. BotTo (ed.), Los Fenicios en la Bahía de Cádiz: Nuevas investigaciones (Collezione di Studi Fenici 46), Pisa - Roma 2014, pp. 51-82.

ZAmora, J.A. - Gener, J.M. - NAVARRo, M.A. - PAJUelo, J.M. - TORRES, M.

2010 Epígrafes fenicios arcaicos en la excavación del Teatro Cómico de Cádiz (2006-2010): Rivista di Studi Fenici XXXVIII-2 (2010), pp. 203-236. 


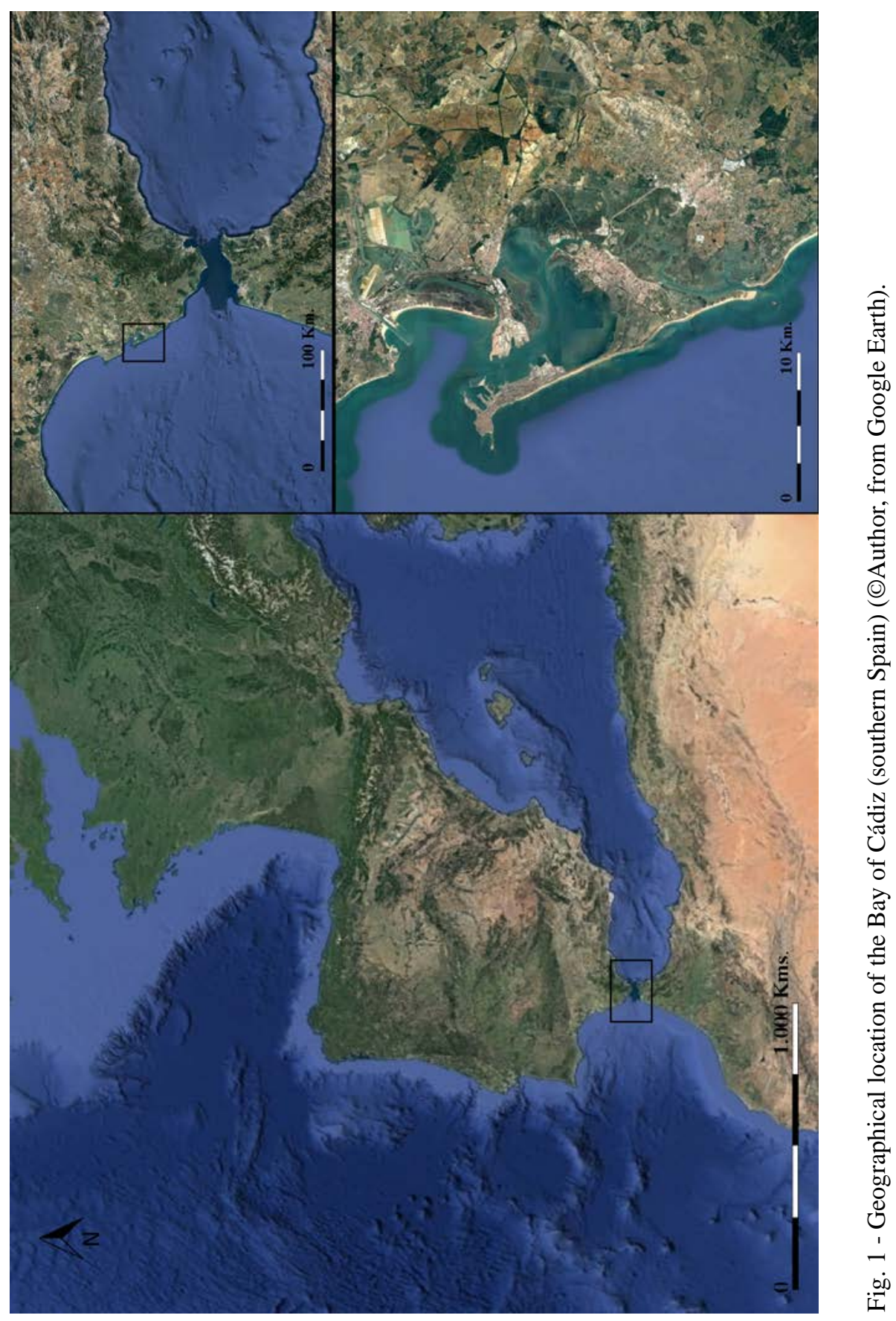



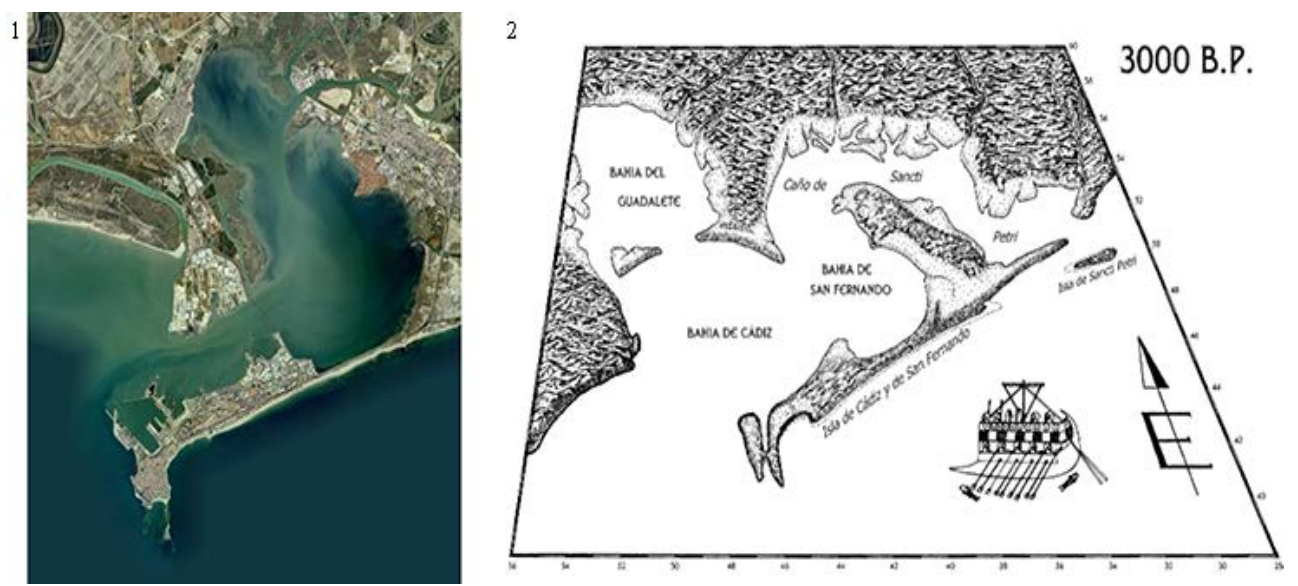

Fig. 2 - Transformation of the landscape (I). 1. Current Bay of Cádiz, aerial view (from Google Earth). 2. Reconstruction of Phoenician Bay of Gadir (Arteaga - Schulz - Roos 2008, 50, fig. 18).
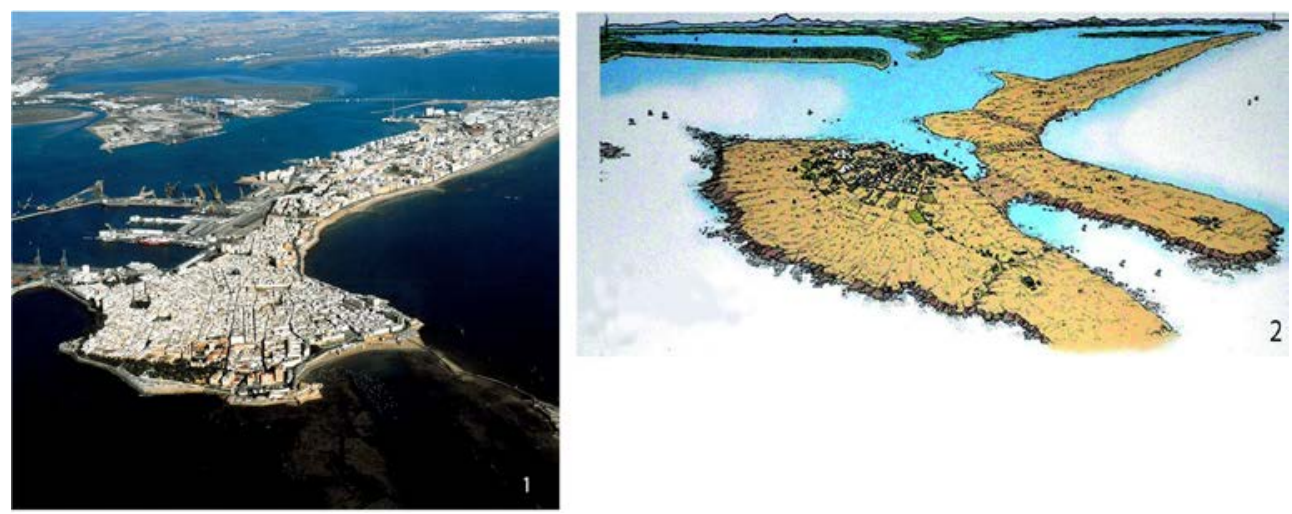

Fig. 3 - Transformation of the landscape (II). 1. Current city of Cádiz, aerial view (http://www.Cádizturismo.com/). 2. The Phoenician city of Gadir, idealized reconstruction (https://es.pinterest.com/pin/455215474809707578). 


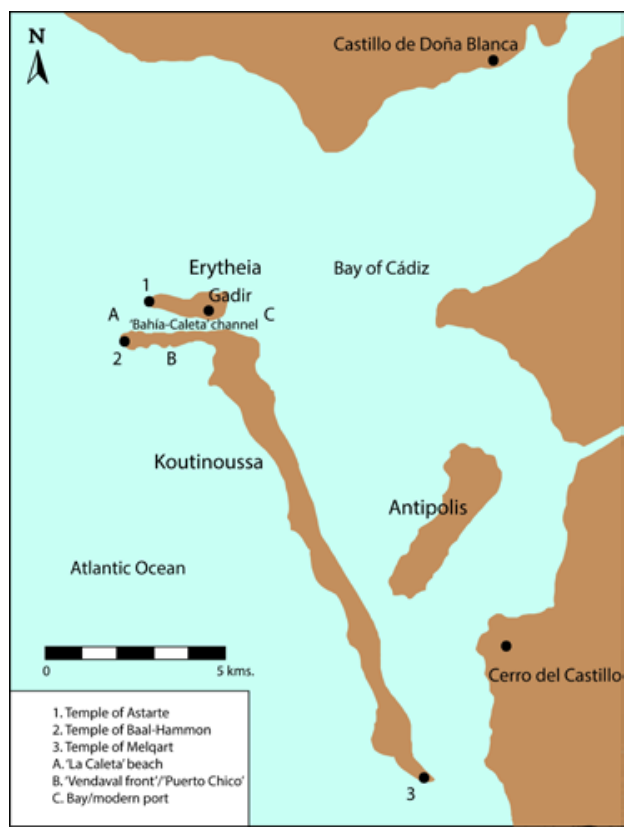

Fig. 4 - Paleo-topography of the Bay of Cádiz during the Phoenician period. With identification of the islands mentioned by the sources (Erytheia, Koutinoussa and Antipolis), the temples (Afrodita-Venus Marina (Astarte), Baal-Hammon/Kronion, Melqart/Herakleion) and the insular (Gadir) and continental settlements (Castillo de Doña Blanca, El Puerto de Santa María and Cerro del Castillo, Chiclana de la Frontera). (c)Author.

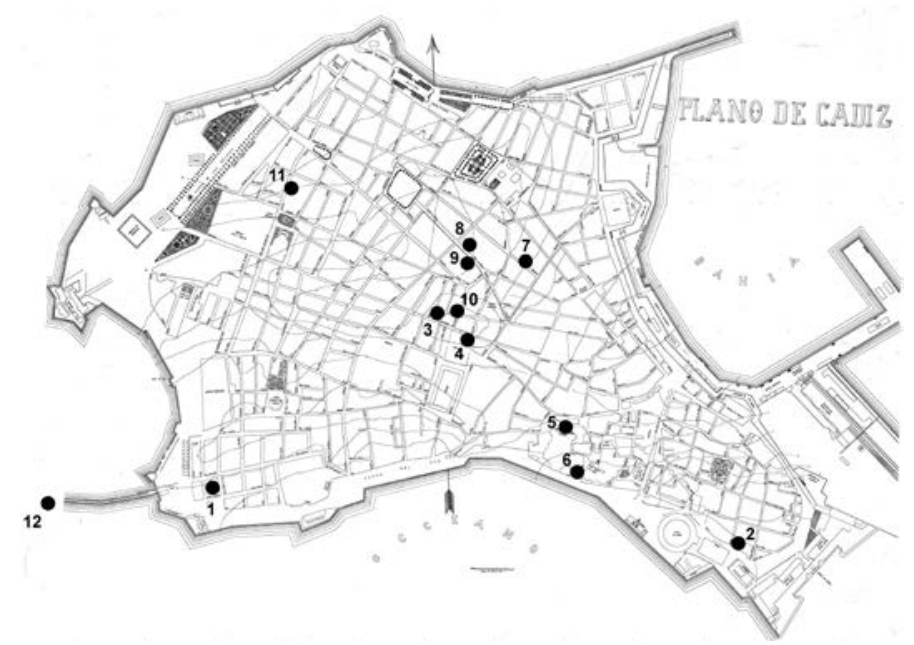

Fig. 5 - Map of current city of Cádiz (Spain) with the location of excavations and sites cited in the text. 1 - C/ Paraguay (CP). 2 - Concepción Arenal/Botica (CAr/CB). 3 - Torre Tavira/Marqués del Real Tesoro (TT/MRT). 4- Teatro Andalucía (TA). 5 - Plaza de la Catedral (PC). 6 - Casa del Obispo (CdO). 7 - Cánovas del Castillo (CdC). 8 - Central Telefónica (CT). 9 - C/ Ancha (CA). 10 - Teatro Cómico (TC). 11 - C/ Hércules (CH). 12Castillo de San Sebastián (CSS). @Author. 

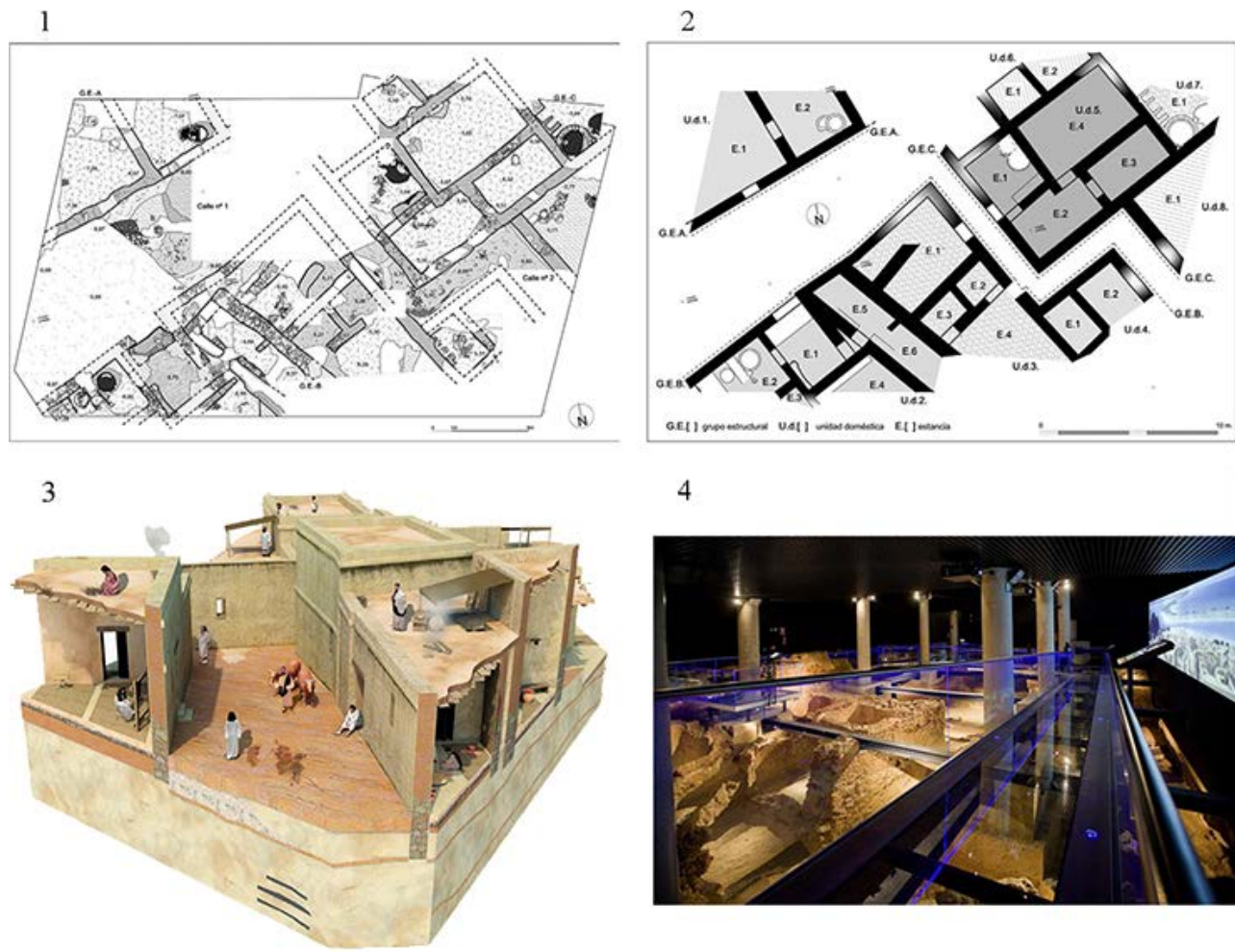

4

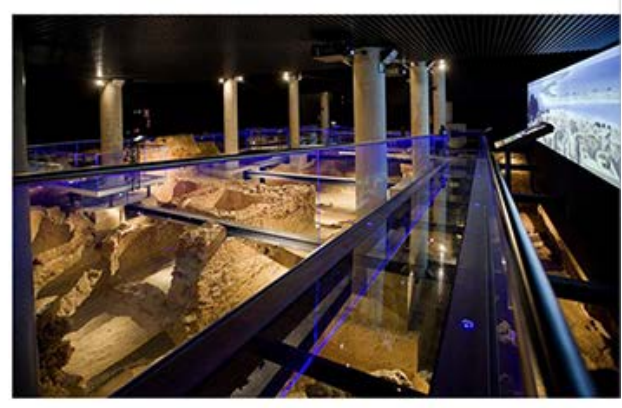

Fig. 6 - Teatro Cómico/Gadir. 1 - Planimetry, Phase II. 2 - Distribution of Phoenician housing, Phase II. 3 - Reconstruction of the Phoenician housing area. 4 - Site musealization. (CTeatro Cómico Team.

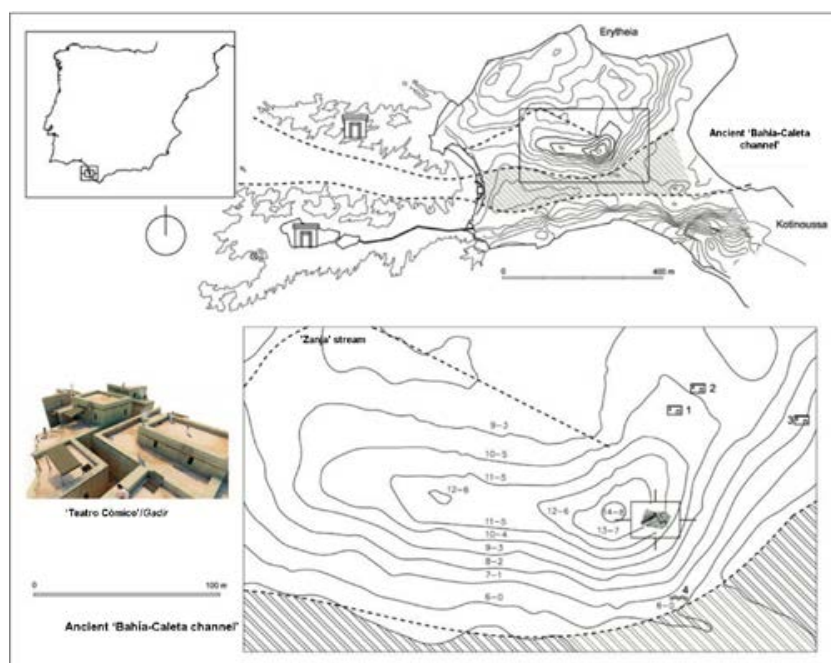

Fig. 7 - Possible extension of the ancient city of Gadir with location of the following sites: Teatro Cómico (in the box), Calle Ancha/CA (1), Central Telefónica/CT (2), Cánovas del Castillo/CdC (3), Teatro Andalucía/TA (4). CTeatro Cómico Team. 

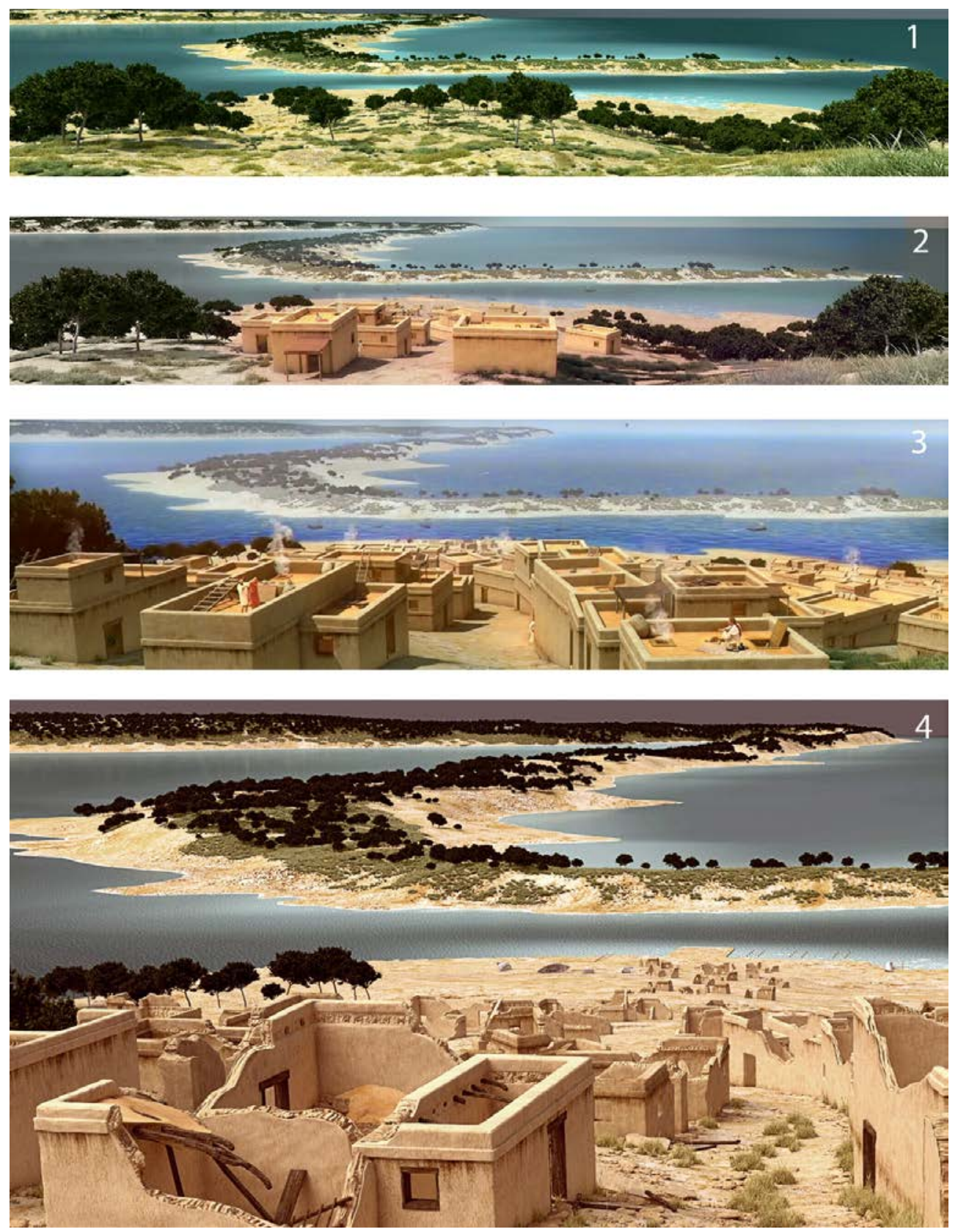

Fig. 8 - Virtual reconstruction of the ancient landscape (1) and evolution of the Phoenician settlement of Teatro Cómico (2, 3, 4)/Gadir. CArtresD-J.A. Cordón. 


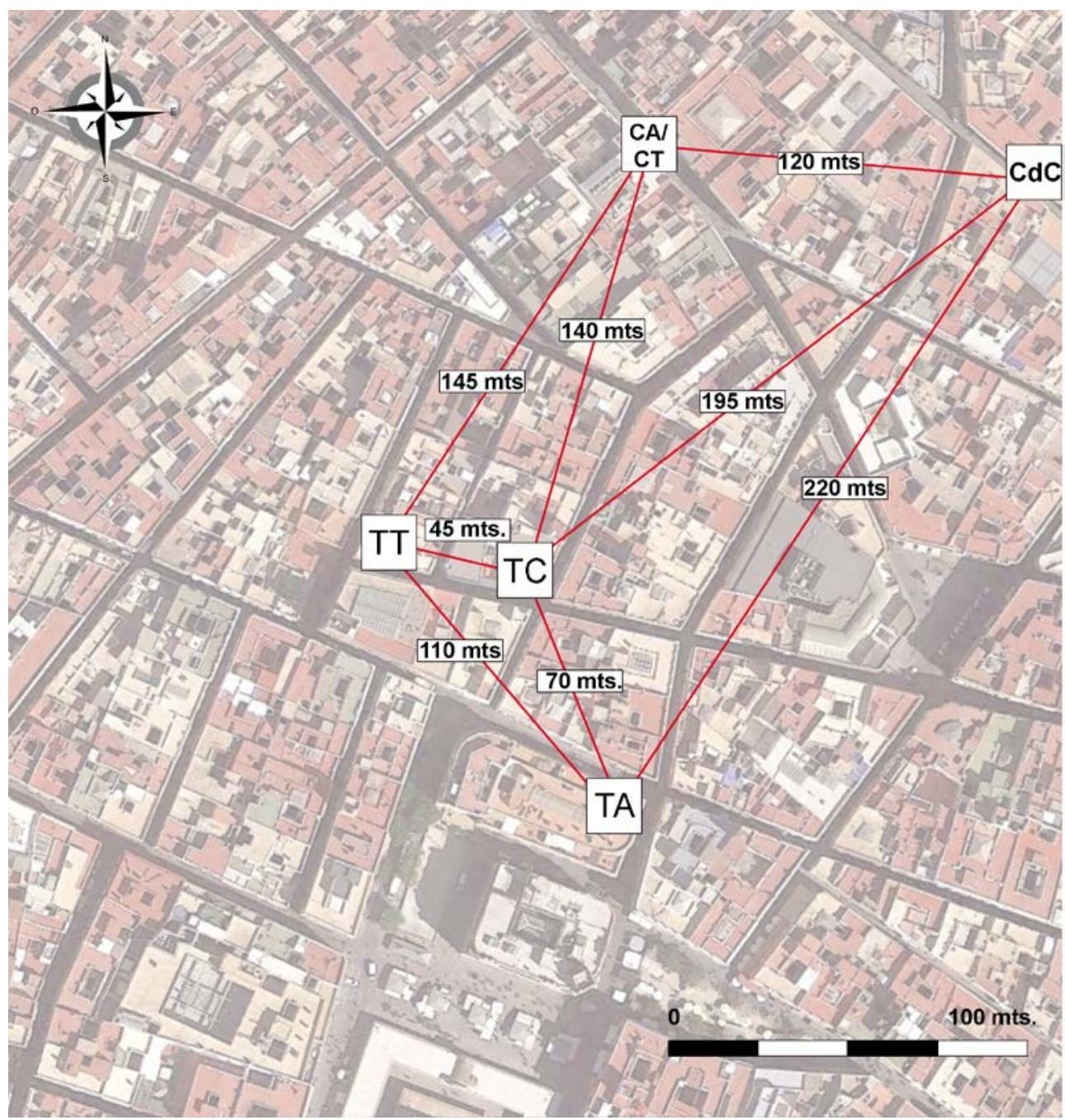

Fig. 9 - Distance between some excavated points in Cádiz. (CModified from Ruiz Mata 2016, fig. 4. 